\title{
Assessment of nutritional knowledge of nurses regarding diet in some diseases
}

\author{
PALLAVI TALUKDAR AND JULIANA SARMAH
}

Received: 14.08.2013; Revised: 03.09.2014; Accepted: 17.09.2014

See end of the paper for authors' affiliations

\section{PALLAVI TALUKDAR}

Department of Extension

Education, College of Home

Science, Assam Agricultural

University, JORHAT (ASSAM)

INDIA

Email: nimitalukdar@yahoo.

co.in

.

